\title{
Eifect of Acute Administration of an Herbal Preparation on Blood Pressure and Heart Rate in Humans
}

\author{
John G. Seifert ${ }^{\bowtie 凶}$, Aaron Nelson², Julia Devonish², Edmund R. Burke³, and Sidney J. Stohs ${ }^{4}$ \\ 1. Movement Science/Human Performance Laboratory, Montana State University, Bozeman, MT, USA \\ 2. Human Performance Laboratory, St. Cloud State University, St. Cloud, MN, USA \\ 3. Dept of Biology, Colorado University - Colorado Springs, Colorado Springs, CO, USA \\ 4. School of Pharmacy and Health Professions, Creighton University Medical Center, Omaha, NE, USA
}

Corresponding author: john.seifert@montana.edu, 406-994-7154

(c) Ivyspring International Publisher. This is an open-access article distributed under the terms of the Creative Commons License (http://creativecommons.org/ licenses/by-nc-nd/3.0/). Reproduction is permitted for personal, noncommercial use, provided that the article is in whole, unmodified, and properly cited.

Received: 2010.10.05; Accepted: 2011.01.31; Published: 2011.03.02

\begin{abstract}
Confusion and controversy exist regarding the cardiovascular effects of dietary supplements containing caffeine and Citrus aurantium (bitter orange) extract. The primary protoalkaloidal ingredient in bitter orange extract is $p$-synephrine which has some structural similarities to ephedrine and nor-epinehrine, but exhibits markedly different pharmacokinetic and receptor binding properties. The goal of this study was to investigate the cardiovascular effects of a product containing caffeine, bitter orange extract ( $p$-synephrine) and green tea extract in mildly overweight individuals. Fourteen female and nine male subjects (age $24.7 \pm 7.4 \mathrm{yrs}$, BMI: $26.6+3.8$ ) volunteered in this randomized, placebo-controlled, crossover, double-blind designed study. On day one, subjects entered the laboratory following an overnight fast. Heart rate and blood pressure were recorded at $60 \mathrm{~min}$. Expired air was analyzed for the next 10 min of the session. At each of three meals, subjects ingested one capsule that was either a non-caloric placebo or a dietary supplement that contained $13 \mathrm{mg}$ p-synephrine and $176 \mathrm{mg}$ caffeine. On the following day, the subjects returned and repeated the protocol for data collection beginning $60 \mathrm{~min}$ after consuming one capsule of the placebo or the dietary supplement. No effects of the dietary supplement on heart rate, systolic and diastolic blood pressure or mean arterial pressure were observed. No between or within group differences were observed when data were analyzed for gender and caffeine usage. A small but significant decrease in resting respiratory exchange ratio was observed for the low caffeine user group in response to the product containing caffeine and $p$-synephrine. The results of this study indicate that ingestion of a product containing bitter orange extract, caffeine and green tea extract does not lead to increased cardiovascular stress and that fat oxidation may increase in certain populations.
\end{abstract}

Key words: Citrus aurantium, $p$-synephrine, blood pressure, heart rate, bitter orange, caffeine, green tea

\section{Introduction}

Approximately two-thirds of the adult American population are overweight while about one-third is by definition considered to be obese [1]. The increase in obesity is associated with increased incidences of di- abetes, hypertension, hyperlipidemias, cardiovascular diseases, stroke, and premature deaths at a cost of billions of dollars annually $[2,3]$. As a consequence, great emphasis is being placed on various approaches 
to weight loss and weight management, including dietary supplements, diets, and exercise programs.

Citrus aurantium (bitter orange) extract and its primary protoalkaloidal constituent $p$-synephrine are widely used in weight loss and weight management products in combination with caffeine, polyphenolics, and other constituents [4-7]. These products are designed to promote thermogenesis and increase metabolism, suppress appetite, and/or slow the absorption of fats and carbohydrates [5].

In spite of their widespread use and the lack of credible reports regarding adverse effects, controversy has existed regarding the safety of bitter orange extract and $p$-synephrine [8-11]. The safety of $p$-synephrine is clouded by its structural similarity to nor-epinephrine in spite of the fact that the pharmacokinetics of the two compounds and the receptor binding specificities are vastly different due to significant structural differences $[5,12]$. Furthermore, there is a lack of understanding $[8,10]$ between the pharmacological properties of $p$-synephrine (hydroxyl group on the para position of the benzene ring) which is found in $C$. aurantium, and $m$-synephrine (phenylephrine; with the hydroxyl group on the meta position) which is used in nasal decongestants and is not a constituent of $C$. aurantium.

Because of the known cardiovascular effects of nor-epinephrine and ephedrine, it has generally been assumed that consumption of $p$-synephrine and bitter orange extract will likewise result in increases in heart rate and blood pressure [8-11]. The purpose of this study was to determine the effects of the acute administration of a product containing caffeine from guarana, $p$-synephrine from $C$. aurantium and a green tea polyphenolic extract on heart rate and blood pressure in mildly overweight human subjects.

\section{Methods}

Twenty-three subjects volunteered to participate in this double blind, placebo controlled cross-over study. Fourteen subjects were female and nine were male. Table 1 summarizes the characteristics of these subjects. The Institutional Review Board approved this study prior to data collection. All subjects completed a health history questionnaire and provided informed consent prior to participation.

An uninvolved individual randomly divided subjects into two groups, 12 and 11 subjects per group. The subjects received either the experimental product in capsule form or a non-caloric placebo in a cross-over design. Following data collection, a one week washout period was provided between the two experimental procedures. Each capsule of the experimental treatment product (Acceleron ${ }^{\circledR}$ ) contained $C$. aurantium extract (AdvantraZ®, 6\% $p$-synephrine yielding $13 \mathrm{mg} p$-synephrine), $176 \mathrm{mg}$ caffeine in the form of guarana extract, and $55.5 \mathrm{mg}$ of green tea extract with small amounts of other ingredients (see Table 2). While on the experimental treatment, each subject consumed four capsules for a total of $52 \mathrm{mg}$ $p$-synephrine and $704 \mathrm{mg}$ caffeine over a 24 hour period.

Table I. Subject characteristics

\begin{tabular}{lllll}
\hline & $\begin{array}{l}\text { Age } \\
(\mathrm{yrs})\end{array}$ & $\begin{array}{l}\text { Height } \\
(\mathrm{m})\end{array}$ & $\begin{array}{l}\text { Weight } \\
(\mathrm{kg})\end{array}$ & BMI \\
\hline Overall & $24.5 \pm 7.4$ & $1.74 \pm 0.09$ & $81.1 \pm 17.1$ & $26.6 \pm 3.8$ \\
$\begin{array}{l}\text { Females } \\
(\mathrm{n}=14)\end{array}$ & $25.4 \pm 9.3$ & $1.68 \pm 0.07$ & $72.4 \pm 11.8$ & $25.5 \pm 3.2$ \\
Males (n=9) & $23.1 \pm 2.5$ & $1.82 \pm 0.06$ & $94.5 \pm 15.7$ & $28.3 \pm 4.1$ \\
\hline
\end{tabular}

BMI: Body mass index. Each value is the mean + SD.

Table 2. Dietary supplement ingredients per capsule

\begin{tabular}{ll}
\hline Ingredient & Amount \\
\hline Guarana (caffeine) & $176 \mathrm{mg}$ \\
Citrus aurantium (p-synephrine) & $13 \mathrm{mg}$ \\
Green Tea Powder Extract & $55.5 \mathrm{mg}$ \\
Bee Pollen & $1 \mathrm{mg}$ \\
White Willow Bark Powder & $1 \mathrm{mg}$ \\
Panax ginseng Root & $2 \mathrm{mg}$ \\
Garcinia cambogia extract & $2 \mathrm{mg}$ \\
Vanadium & $0.15 \mathrm{mcg}$ \\
\end{tabular}

On a given treatment, day one was used to collect baseline data. All subjects were instructed to refrain from exercise 24 hours before their trial. Dietary intake was not controlled, but subjects were instructed to maintain a consistent intake from trial to trial. Subjects entered the laboratory on the scheduled morning following an overnight (12 hour) fast. They sat quietly for $30 \mathrm{~min}$ in a comfortable chair in a room with dim light.

Expired air was collected for $10 \mathrm{~min}$ from 20 to $30 \mathrm{~min}$ of this session as subjects breathed through a one-way breathing valve. Expired air was collected in Douglas bags and contents measured by Ametek Oxygen and Carbon Dioxide Analyzers (Thermox, Pittsburgh, PA) while volume was measured using a Tissot spirometer. Indirect calorimetry was used to determine oxygen uptake $\left(\mathrm{VO}_{2}\right)$ and carbon dioxide production $\left(\mathrm{VCO}_{2}\right)$. The non-protein respiratory exchange ratio (RER) value was calculated from $\mathrm{VO}_{2}$ and $\mathrm{VCO}_{2}$. The RER was used as an index of fat and carbohydrate oxidation. Heart rate (Polar HR Moni- 
tor, Stamford, CT) and blood pressure (ausculatory method) were collected at $30 \mathrm{~min}$.

Following baseline data collection, subjects were given three treatment capsules and instructed to ingest one capsule with each meal during that day. Subjects returned to the laboratory on the following morning after an overnight fast and were given the fourth treatment capsule with water. Subjects then sat quietly for $60 \mathrm{~min}$. The $60 \mathrm{~min}$ period was estimated to give maximal blood levels of the ingredients [11, 13]. Expired air was then collected and analyzed during the next $10 \mathrm{~min}$ of the session. Heart rate and blood pressure were recorded at the end of expired air collection, approximately 72-75 $\mathrm{min}$ after capsule ingestion.

Three analyses of the data were performed using $2 \times 2$ analysis of variance (ANOVA). For the first data analysis, treatment and time were the independent factors using all 23 subjects. The second analysis separated and analyzed the data according to gender. The third analysis assessed the data for differences in high caffeine and low-caffeine users. Fourteen subjects were classified as low caffeine users and nine as high caffeine users, employing the breakpoint of 150 $\mathrm{mg}$ caffeine per day to separate the two groups. Statistical significance was established at $p<0.05$. All data are reported as mean \pm standard deviation (SD).

\section{Results}

All 23 subjects completed the study. Based on self-report and questionnaire, all subjects ingested the given capsules on time as noted in the Methods section. No adverse treatment effects were observed or reported by any of the subjects.

Table 3 contains the cardiovascular data from the entire subject population. No statistical differences were observed within groups or between groups for any of the measures. Heart rate, blood pressure, and metabolic variables were maintained from baseline to the post-ingestion collection period regardless of treatment. Three subjects (one male and two females) were pre-existing hypertensives (systolic blood pressure $>140 \mathrm{~mm} \mathrm{Hg}$ ). Blood pressures for the hypertensive individuals did not change significantly in response to the dietary supplement.

Table 4 contains data separated by gender. No significant differences were observed for the dependent variables in the female group. Likewise, males did not demonstrate significant differences when the dietary supplement was ingested.

Data separated into high and low caffeine users are presented in Table 5. As with the previous analyses, no significant differences were observed for heart rates or blood pressures between the experi- mental and placebo control groups. However, there was a small but significant change in RER data for the low caffeine users relative to both the placebo control group and the pre-treatment baseline for the low caffeine group. After ingestion of dietary supplement the low caffeine users exhibited a decrease in RER from $0.84 \pm 0.05$ to $0.81 \pm 0.04$.

Effect sizes were calculated for each of the analyses where data were separated by gender (Table 4) or caffeine consumption (Table 5). The effects based on number of subjects per group were all below 0.4 , indicating low to moderate influence.

Table 3. The effects of supplementation on cardiovascular and metabolic parameters $(n=23)$

$\begin{array}{llllll}\text { Treatment } & \begin{array}{l}\text { Heart } \\ \text { Rate } \\ (\mathrm{bpm})\end{array} & \begin{array}{l}\text { Systolic } \\ \mathrm{BP}(\mathrm{mm})\end{array} & \begin{array}{l}\text { Diastolic } \\ \mathrm{BP}(\mathrm{mm}\end{array} & \begin{array}{l}\text { MAP } \\ (\mathrm{mm})\end{array} & \text { RER } \\ & 62.4 & 119.9 & 77.7 \pm 8.9 & 91.8 \pm & 0.85 \\ \text { PL pre } & \pm 11.8 & \pm 12.0 & & 9.1 & \pm 0.07 \\ & 60.7 & 118.7 & 76.7 \pm 7.8 & 90.7 \pm & 0.86 \\ \text { PL post } & \pm 12.5 & \pm 10.2 & & 8.5 & \pm 0.05 \\ & 63.5 & 119.2 & 76.9 \pm 8.4 & 91.0 \pm & 0.85 \\ \text { DS pre } & \pm 14.2 & \pm 14.3 & & 9.8 & \pm 0.06 \\ & 60.9 & 118.9 & 79.2 \pm 6.4 & 92.4 \pm & 0.83 \\ \text { DS post } & \pm 12.4 & \pm 11.1 & & 7.3 & \pm 0.07 \\ & & & & & \end{array}$

PL: Placebo; DS: Dietary Supplement; BP: Blood Pressure; MAP: Mean Arterial Pressure; RER: Respiratory Exchange Ratio. Each value is the mean $\pm S D$.

Table 4. The effect of gender and supplementation on cardiovascular and metabolic parameters

\begin{tabular}{llllll}
\hline Treatment & $\begin{array}{l}\text { Heart } \\
\text { Rate } \\
(\mathrm{bpm})\end{array}$ & $\begin{array}{l}\text { Systolic } \\
\mathrm{BP}(\mathrm{mm})\end{array}$ & $\begin{array}{l}\text { Diastolic } \\
\mathrm{BP}(\mathrm{mm}) \\
\mathrm{Hg})\end{array}$ & $\begin{array}{l}\text { MAP } \\
(\mathrm{mm})\end{array}$ & RER \\
& & & & & \\
\hline $\begin{array}{l}\text { A. Females } \\
(\mathrm{n}=14)\end{array}$ & & & & & \\
& & & & & \\
PL pre & 65.9 & 117.9 & 76.3 & 90.1 & 0.86 \\
& \pm 13.2 & \pm 12.6 & \pm 10.5 & \pm 10.4 & \pm 0.08 \\
PL post & 65.1 & 117.2 & $76.1 \pm 8.9$ & 89.8 & 0.85 \\
& \pm 13.1 & \pm 12.6 & & \pm 9.5 & \pm 0.05 \\
DS pre & 70.2 & 112.8 & $74.2 \pm 8.8$ & 87.1 & 0.84 \\
& \pm 13.8 & \pm 12.4 & & \pm 9.4 & \pm 0.05 \\
DS post & 65.5 & 116.2 & $79.4 \pm 5.9$ & 91.7 & 0.82 \\
& \pm 12.4 & \pm 10.3 & & \pm 7.0 & \pm 0.09 \\
B. Males & & & & & \\
(n=9) & & & & & \\
PL pre & 56.9 & 123.0 & $80.0 \pm 5.2$ & 94.3 & 0.85 \\
& \pm 6.3 & \pm 11.0 & & \pm 6.4 & \pm 0.05 \\
PL post & 53.9 & 120.9 & $77.7 \pm 6.3$ & 92.1 & 0.86 \\
& \pm 8.0 & \pm 11.9 & & \pm 7.2 & \pm 0.05 \\
DS pre & 53.1 & 128.1 & $91.0 \pm 6.2$ & 97.1 & 0.85 \\
& \pm 7.0 & \pm 11.4 & & \pm 7.3 & \pm 0.06 \\
DS post & 53.8 & 123.0 & $78.8 \pm 7.5$ & 93.5 & 0.83 \\
& \pm 8.8 & \pm 11.6 & & \pm 8.0 & \pm 0.05 \\
\hline
\end{tabular}

PL: Placebo; DS: Dietary Supplement; BP: Blood Pressure; MAP: Mean Arterial Pressure; RER: Respiratory Exchange Ratio. Each value is the mean $+\mathrm{SD}$. 
Table 5. The effects of caffeine use and supplementation on physiological responses.

\begin{tabular}{|c|c|c|c|c|c|}
\hline Treatment & $\begin{array}{l}\text { Heart } \\
\text { Rate } \\
\text { (bpm) }\end{array}$ & \begin{tabular}{l}
\multicolumn{2}{c}{ Systolic } \\
$\mathrm{BP}$ \\
$\mathrm{Hg})$
\end{tabular} & $\begin{array}{l}\text { Diastolic } \\
\mathrm{BP} \quad(\mathrm{mm} \\
\mathrm{Hg})\end{array}$ & $\begin{array}{l}\text { MAP } \\
(\mathrm{mm} \\
\mathrm{Hg})\end{array}$ & RER \\
\hline \multicolumn{6}{|l|}{$\begin{array}{l}\text { A. Low } \\
\text { Caffeine } \\
\text { Users } \\
(n=14)\end{array}$} \\
\hline PL pre & $\begin{array}{l}63.4 \\
\pm 11.9\end{array}$ & $120.6 \pm 12.1$ & $79.8 \pm 9.6$ & $\begin{array}{l}93.4 \\
\pm 9.7\end{array}$ & $\begin{array}{l}0.84 \\
\pm 0.06\end{array}$ \\
\hline PL post & $\begin{array}{l}63.4 \\
\pm 13.1\end{array}$ & $117.9 \pm 12.7$ & $78.1 \pm 8.2$ & $\begin{array}{l}91.3 \\
\pm 8.9\end{array}$ & $\begin{array}{l}0.84 \\
\pm 0.04\end{array}$ \\
\hline DS pre & $\begin{array}{l}65.8 \\
(15.2\end{array}$ & $119.4 \pm 13.6$ & $77.9 \pm 9.2$ & $\begin{array}{l}91.8 \\
\pm 10.3\end{array}$ & $\begin{array}{l}0.84 \\
\pm 0.05\end{array}$ \\
\hline DS post & $\begin{array}{l}64.7 \\
(13.7\end{array}$ & $120.6 \pm 11.1$ & $80.6 \pm 6.3$ & $\begin{array}{l}94.0 \\
\pm 7.3\end{array}$ & $\begin{array}{l}0.81 \\
\pm 0.04^{*}\end{array}$ \\
\hline \multicolumn{6}{|l|}{$\begin{array}{l}\text { B. High } \\
\text { Caffeine } \\
\text { Users } \\
(n=9)\end{array}$} \\
\hline PL pre & $\begin{array}{l}60.9 \\
\pm 12.1\end{array}$ & $118.8 \pm 12.5$ & $74.6 \pm 7.0$ & $\begin{array}{l}89.3 \\
\pm 8.1\end{array}$ & $\begin{array}{l}0.87 \\
\pm 0.09\end{array}$ \\
\hline PL post & $\begin{array}{l}56.7 \\
\pm 10.9\end{array}$ & $119.8 \pm 12.2$ & $74.7 \pm 7.2$ & $\begin{array}{l}89.7 \\
\pm 8.3\end{array}$ & $\begin{array}{l}0.88 \\
\pm 0.06\end{array}$ \\
\hline DS pre & $\begin{array}{l}60.0 \\
\pm 12.6\end{array}$ & $118.9 \pm 16.2$ & $75.2 \pm 7.2$ & $\begin{array}{l}89.8 \\
\pm 9.5\end{array}$ & $\begin{array}{l}0.86 \\
\pm 0.06\end{array}$ \\
\hline DS post & $\begin{array}{l}55.0 \\
\pm 7.3\end{array}$ & $116.1 \pm 11.1$ & $76.9 \pm 6.2$ & $\begin{array}{l}90.0 \\
\pm 7.0\end{array}$ & $\begin{array}{l}0.86 \\
\pm 0.10\end{array}$ \\
\hline
\end{tabular}

*Significantly different from pre-ingestion value and placebo groups $(\mathrm{P}<0.05)$.

PL: Placebo; DS: Dietary Supplement; Heart Rate; BP: Blood Pressure; MAP: Mean Arterial Pressure; RER: Respiratory Exchange

Ratio. Each value is the mean $+\mathrm{SD}$.

\section{Discussion}

The results of this study indicate that acute ingestion of a dietary supplement containing caffeine, bitter orange extract ( $p$-synephrine) and green tea extract did not lead to significant cardiovascular effects as reflected by blood pressure and heart rate, regardless of treatment or subject grouping either by gender or caffeine usage. Subjects in the present study ingested $39 \mathrm{mg}$ of $p$-synephrine and $528 \mathrm{mg}$ of caffeine the day before testing followed by ingestion of an additional $13 \mathrm{mg}$ p-synephrine and $176 \mathrm{mg}$ caffeine the next morning after an overnight fast. This protocol more closely represents typical ingestion regimes of dietary supplements used for weight loss and weight management, and is unique as compared to other studies that involve only a single dose [11, 13-15].

Controversy exists regarding the cardiovascular effects of C. aurantium extract in combination with caffeine, and various authors make the assumption that an increase in heart rate and blood pressure are to be expected $[8,10,16-19]$. However, a number of studies that have assessed the cardiovascular effects of products composed of $C$. aurantium extract in com- bination with caffeine and other ingredients have not observed an increase in blood pressure $[6,7,11,19-21]$ or heart rate $[6,7,19-21]$. The results of the present study clearly agree with these previous observations.

Haller et al. [11] examined the cardiovascular effects associated with a single dose of a multi-component dietary supplement (Xenadrine $\left.{ }^{\circledR}\right)$ in 10 subjects. The supplement contained $5.5 \mathrm{mg}$ p-synephrine, $239 \mathrm{mg}$ caffeine, $5.7 \mathrm{mg}$ octopamine and undisclosed amounts of other ingredients including catechin polyphenols. The hemodynamic effects of a single dose of a C. aurantium extract (Advantra $Z^{\circledR}$ ) that contained $46.9 \mathrm{mg} p$-synephrine were also examined. The results demonstrated that the dietary supplement, but not the $p$-synephrine-containing bitter orange extract, increased both systolic and diastolic blood pressures at two hours post treatment relative to the control group. No significant effects of either treatment on heart rate were noted over the first three hours after ingestion of the products. However, a significant increase in heart rate over control was noted at the six hour time point.

This study of Haller et al. [11] is complicated by the fact that all subjects consumed a meal three hours after treatment ingestion. After eating, an increase in heart rate occurred in all three treatment groups. The increase in heart rate does not coincide with the pharmacokinetics including blood levels and half-life of $p$-synephrine [11, 13], but does coincide with the thermic effect of food in this study. Given that the control group responded similarly to the two treatment groups after the meal at the four and eight hour measurements (one and five hours after the meal), the reason for the apparently significant difference seen at only the six hour time point (three hours after the meal) is unclear. No explanation is given by the authors for this change in heart rate. Gougeon et al. [19] reported that the thermic effect of food increased by $29 \%$ in 17 females after they ingested $26 \mathrm{mg}$ $p$-synephrine. The thermic effect of $p$-synephrine was greater in males than females in the absence of a meal, and no significant changes occurred in pulse rates or blood pressures when compared with baseline values.

Haller et al. [13] have also examined the effects, under resting and exercise conditions, of a dietary supplement designed to enhance athletic performance in 10 subjects. The product (Ripped Fuel Extreme $\mathrm{Cut}^{\circledR}$ ) contained $21 \mathrm{mg} p$-synephrine, $304 \mathrm{mg}$ caffeine, as well as extracts of green tea, ginger root, cocoa seed, willow bark and wasabi. The placebo or product was taken one hour before 30 min of moderately intense exercise. There were no treatment- related differences in post-exercise heart rate, systolic blood pressure or body temperature. A significant prod- 
uct-related increase in diastolic blood pressure $(8.7$ $\mathrm{mm} \mathrm{Hg}$ ) was observed, apparently counteracting the vasodilatory effects of exercise. Due to the poly-herbal, poly-alkaloidal and poly-protoalkaloidal nature of this product, the ingredient or ingredients responsible for the observed effect cannot be determined.

Bui et al. [15] conducted a study on 15 healthy subjects given a single oral dose of $900 \mathrm{mg}$ bitter orange extract (Nature's Way) that contained $6 \%$ $p$-synephrine (54 mg $p$-synephrine) or the placebo. Small but significant increases were observed in heart rate, and systolic and diastolic blood pressures for up to five hours. Of interest is the fact that Min et al. [18] used this same product in a similarly designed study and saw no effect in 18 subjects on systolic or diastolic blood pressure, or on the rate-corrected QT (QTc) interval.

The confusion regarding the purported cardiovascular effects of $C$. aurantium has been due, at least in part, to a lack of understanding of the differences in the pharmacokinetic and pharmacological properties between $p$-synephrine and $m$-synephrine (phenylephrine). Failure to differentiate the effects of the two isomers has resulted in a number of authors attributing the effects of $m$-synephrine to $p$-synephrine [see for example 8, 10,17, 18, 21]. $p$-Synephrine (hydroxyl group in the para position on the benzene ring) is the isomeric form found in C. aurantium (bitter orange). $m$-Synephrine (hydroxyl group in the meta position) is not a constituent of bitter orange nor is it present in standardized $C$. aurantium reference materials [22]. The $m$-synephrine (phenylephrine) is readily available as an over-the-counter nasal decongestant, is also used as an ophthalmic product for mydriasis, and is known for its cardiovascular effects [23].

The differences in pharmacological properties of the $m$ - and $p$-isomers of synephrine can be explained on the basis of adrenergic receptor binding. It is well known that, in general, binding to a-adrenergic receptors results in vasoconstriction, with increased cardiovascular contractility and increased heart rate occurring in response to $\beta 1$-adrenergic receptor binding, while bronchodilation occurs in response to $\beta 2$-adrenergic receptor binding [24]. Activation of $\beta 3$-adrenoreceptors is believed to be associated with lipolysis and thermogenesis, and not adverse cardiovascular effects [25]. The belief that $p$-synephrine exerts its effects by binding primarily to this receptor is supported by experimental [26] and receptor binding studies [27].

The cardiovascular effects of caffeine are known to depend on the extent of regular exposure [28, 29]. Caffeine-naïve subjects can experience an increase in blood pressure and heart rate, while regular users of caffeine-containing products develop a tolerance to these effects. In this study, even the low caffeine users did not demonstrate an increase in these cardiovascular effects. The observation that the low caffeine intake group showed a reduction in RER may be a reflection of caffeine sensitivity. Caffeine is known to increase fat oxidation (lower RER), and this group may have been more responsive to the caffeine in the product.

Although the number of subjects used in this study is not large $(n=23)$, this number exceeds the number of subjects used in frequently referenced studies involving bitter orange extract. For example, Haller et al. [11, 13] used 10 subjects in each study, while Sale et al.[20] used 20 subjects, Bui et al. [15] used 15 subjects and Min et al. [14] used 18 subjects. Furthermore, as noted in the results, because of the small numbers of subjects when the data were separated based on gender and caffeine intake, size effects were calculated for each of these analyses. The effects of size were low (0.2) for gender and moderate (0.4) for the low caffeine users with respect to RER.

In summary, the results of this study indicate that ingestion of a product containing bitter orange extract ( $p$-synephrine), caffeine and green tea extract in a short-term dosing schedule similar to that commonly used with dietary supplements did not result in alterations in heart rate or blood pressure. However, longer term studies are required to assess these effects under conditions similar to those encountered when using the product in conjunction with a long term weight loss program.

\section{Acknowledgements}

The authors would like to thank the subjects for their cooperation. This study was funded by a grant from Enforma Natural Products. This article is dedicated to Dr. Ed Burke, who passed away before the completion of this paper.

\section{Conflict of Interest}

The authors have declared that no conflict of interest exists.

\section{References}

1. Flegal KM, Carroll MD, Ogden CL, et al. Prevalence and trends in obesity among US adults, 1999-2008. J Amer Med Assoc. 2010; 303(3): 235-241.

2. Lubitz CL, Flegal KM, Pamuk ER. The predicted effects of chronic obesity in middle age on medicare costs and mortality. Med Care. 2010; 48(6): 510-517.

3. Barkin SL, Heerman WJ, Warren MD, et al. Millennials and the world of work: the impact of obesity on health and productivity. J Bus Psychol. 2010; 25(2): 239-245. 
4. Preuss HG, DiFerdinando D, Bagchi M, et al. Citrus aurantium as a thermogenic, weight-reduction replacement for ephedra: an overview. J Med. 2002; 33: 247-264.

5. Stohs SJ, Shara M. A review of the safety and efficacy of Citrus aurantium in weight management. In: Bagchi D and Preuss HG, editors. Obesity: epidemiology, pathophysiology, and prevention. Boca Raton (FL): CRC Press; 2007: 371-382.

6. Colker CM, Kalman DS, Torina GC, et al. Effects of Citrus aurantium extract, caffeine and St. John's wort on body fat loss, lipid levels and mood states in normal weight and obese individuals. Curr Therap Res. 1999; 60: 145-153.

7. Zenk JL, Leikam SA, Kassen LJ, et al. Effect of Lean System 7 on metabolic rate and body composition. Nutrition 2005; 21: 179-185.

8. Bent S, Padula A, Neuhaus J. Safety and efficacy of citrus aurantium for weight loss. Am J Cardiol. 2004; 94:1359-1361.

9. Fugh-Berman A, Myers A. Citrus aurantium, an ingredient of dietary supplements marketed for weight loss: current status of clinical and basic research. Exp Biol Med. 2004; 229:698-704.

10. Penzak SR, Jann MW, Cold JA, et al. Seville (sour) orange juice: synephrine content and cardiovascular effects in normotensive adults. J Clin Pharmacol. 2001; 41:1059-1063.

11. Haller CA, Benowitz NL, Jacob IIIP. Hemodynamic effects of ephedra-free weight-loss supplements in humans. Am J Med. 2005; 118:998-1003.

12. Stohs SJ, Preuss HG. The Safety of bitter orange (Citrus aurantium) and its primary alkaloid p-synephrine. HerbalGram 2011; 89: 34-39.

13. Haller CA, Duan M, Peyton J III, et al. Human pharmacology of a performance-enhancing dietary supplement under resting and exercise conditions. Brit J Clin Pharmacol. 2008; 65: 833-840.

14. Min B, Cios D, Kluger J, et al. Absence of QTc-interval-prolonging or hemodynamic effects of a single dose of bitter orange extract in healthy subjects. Pharmacotherapy. 2005; 25: 1719-1724.

15. Bui LT, Nguyen DT, Ambrose PJ. Blood pressure and heart rate effects following a single dose of bitter orange. Ann Pharmacodyn. 2006; 40: 53-57.

16. Gray S, Woolf AD. Citrus aurantium used for weight loss by an adolescent with anorexia nervosa. J Adol Hlth. 2005; 37: 415-416.

17. Thomas JE, Munir JA, McIntyre PZ, et al. STEMI in a 24-year-old man after use of a synephrine-containing dietary supplement. A case report and review of the literature. Texas Heart Inst J. 2009; 36: 586-590.

18. Stephensen TA, Sarlay Jr R. Ventricular fibrillation associated with use of synephrine containing dietary supplement. Military Med. 2009; 174:1313-1319.

19. Gougeon R, Harrigan K, Tremblay JF, et al. Increase in the thermic effect of food in women by adrenergic amines extracted from citrus aurantium. Obesity Res. 2005; 13: 1187-1194.

20. Sale C, Harris RC, Delves S, et al. Metabolic and physiological effects of ingesting extracts of bitter orange, green.tea and guarana at rest and during treadmill walking in overweight males. Int J Obesity 2006; 30: 764-773

21. Smedema JP, Muller GJ. Coronary spasm and thrombosis in a bodybuilder using a nutritional supplement containing synephrine, octopamine, tyramine and caffeine. So African Med J. 2008; 98: 372-373.

22. Sander LC, Putzbach K, Nelson BC, et al. Certification of standard reference materials containing bitter orange. Analyt Bioanalyt Chem. 2008; 391: 2023-2034.

23. Stewart A, Fernando R, McDonald S, et al. The dose-dependent effects of phenylephrine for elective cesarean delivery under spinal anesthesia. Anesth Analg. 2010 [epub ahead of print].
24. Inchiosa MAJr. "Evidence (mostly negative) with the use of sympathomimetic agents for weight loss". J Obesity 2011 [epub ahead of print].

25. Arch JR. $\beta$-3-Adrenoreceptor agonists: potential, pitfalls and progress. Eur J Pharmacol. 2002; 440: 99-107.

26. TsujitaT, Takaku T. Lipolysis induced by segment wall extract from Satsuma mandarin orange (Citrus unshu Mark). J Nutr Sci Vitaminol. 2007; 53: 547-551.

27. Carpene C, Galitzky J, Fontana E, et al. Selective activation of beta 3-adrenoreceptors by octopamine: comparative studies in mammalian fat cells. Naunyn Schmiedebergs Arch Pharmacol. 1999; 359: 310-321.

28. Dews PB. Caffeine. Ann Rev Nutr. 1982; 2: 323-341.

29. Dews PB, O'Brien CP, Bergman J. Caffeine: behavioral effects of withdrawal and related issues. Food Chem Tox. 2003; 40: 1257-1261. 